Check for updates

Cite this: RSC Adv., 2018, 8, 27919

Received 3rd May 2018

Accepted 26th July 2018

DOI: $10.1039 / \mathrm{c} 8 \mathrm{ra} 03815 \mathrm{e}$

rsc.li/rsc-advances

\section{Synthesis of $\beta$-alkoxy- $N$-protected phenethylamines via one-pot copper-catalyzed aziridination and ring opening $\dagger$}

\author{
Jorge Saavedra-Olavarría, ${ }^{a}$ Matías Madrid-Rojas, ${ }^{\mathrm{b}}$ Iriux Almodovar, \\ Patricio Hermosilla-lbáñez ${ }^{b}$ and Edwin G. Pérez (iD *a
}

A regioselective, copper-catalyzed, one-pot aminoalkoxylation of styrenes using primary and secondary alcohols and three different iminoiodanes as alkoxy and nitrogen sources respectively, is reported. The $\beta$-alkoxy- $N$ protected phenethylamines obtained were used to synthesise $\beta$-alkoxy- $N$-benzylphenethylamines which are interesting new compounds that could act as possible neuronal ligands.
Aziridines are an important class of nitrogen-containing heterocycles that can be found in a number of biologically active compounds ${ }^{1}$ and have also been synthesised by several routes. $^{2}$ Aziridines are suitable synthetic scaffolds or intermediates for the synthesis of many kinds of organic compounds through their ring opening by different nucleophiles including cyanide, aromatic and olefinic compounds, hydride, alcohols, thiols, amines, and halogens, affording various 1,2-difunctionalised compounds. ${ }^{3}$ Among these 1,2-difunctionalised products, vicinal amino ethers have been obtained using different methodologies including inorganic protic or Lewis acids such as $\mathrm{BF}_{3} \cdot \mathrm{Et}_{2} \mathrm{O}, \quad \mathrm{Sn}(\mathrm{OTf})_{2}, \quad\left(\mathrm{NH}_{4}\right)_{2} \mathrm{Ce}\left(\mathrm{NO}_{3}\right)_{6}$, ionic liquids, $\left[\mathrm{Ag}(\mathrm{COD})_{2}\right] \mathrm{PF}_{6}$, and also by an aprotic imidazolium zwitterion, an $N, N^{\prime}$-dioxide-Mg(OTf $)_{2}$ complex, sulphated zirconia, $\mathrm{Ag}(\mathrm{I})$, $\mathrm{Au}(\mathrm{I})$, phosphomolybdic acid supported on silica gel, montmorillonites and ceric ammonium nitrate, but always using previously isolated aziridines. ${ }^{4}$ In addition, very recently, the aziridination of alkenes with subsequent ring opening using alcohols under continuous flow was reported. ${ }^{5}$ As far as we know, only a small number of one-pot methodologies has been reported using rhodium, iron(II) phthalocyanine and ruthenium as the catalysts and different nucleophiles to generate $\mathrm{N}$-protected difunctionalised alkenes. However, the number of $\mathrm{N}$ protected $\beta$-amino ethers is limited. ${ }^{6}$

$N$-Protected $\beta$-aminophenyl ethers are useful intermediates in the synthesis of substituted indolines, ${ }^{7}$ and the corresponding $N$-deprotected $\beta$-alkoxyphenethylamines have shown some

${ }^{a}$ Department of Organic Chemistry, Faculty of Chemistry, Pontificia Universidad Católica de Chile, Av. Vicuña Mackenna 4860, Casilla 306, Correo 22, Santiago, Chile.E-mail: eperezh@uc.cl

${ }^{b}$ Facultad de Quimica y Biología, Universidad de Santiago de Chile, USACh, Santiago, Chile

$\dagger$ Electronic supplementary information (ESI) available: CCDC 1835571. For ESI and crystallographic data in CIF or other electronic format see DOI: 10.1039/c8ra03815e interesting biological activities. ${ }^{8}$ For these reasons, we decided to look for a one-pot aziridination-ring opening process but using inexpensive copper catalysts and combining different styrenes, alcohols and phenyl iminoiodinanes.

\section{Results and discussion}

Initially, and based on a recent methodology reported by us, we decided to use styrene (1a) as a model substrate, $\mathrm{Cu}(\mathrm{MeCN})_{4} \mathrm{BF}_{4}$ and neocuproine as the catalyst and ligand respectively, with $\mathrm{Ph}-\mathrm{I}=\mathrm{N}$-Ts acting as the nitrene source, plus methanol. ${ }^{9}$ In addition, we chose $\mathrm{Mo}(\mathrm{CO})_{6}$ as an additive to improve the yield. ${ }^{10}$ Using the conditions mentioned in Table 1 , entry $1, N$ tosyl- $\beta$-methoxyphenethylamine (2a) was obtained in $48 \%$ yield, while none of this desired product was formed when the copper salt was omitted under similar conditions (entry 2). Replacing $\mathrm{Cu}(\mathrm{MeCN})_{4} \mathrm{BF}_{4}$ with $\mathrm{Cu}\left(\mathrm{BF}_{4}\right)_{2} \cdot \mathrm{H}_{2} \mathrm{O}$ the yield increased slightly (entry 3). Conversely, when $\mathrm{Cu}\left(\mathrm{BF}_{4}\right)_{2} \cdot \mathrm{H}_{2} \mathrm{O}$ and nitromethane were used as the catalyst and solvent, the isolated yield increased to $74 \%$ (Table 1, entry 4). Additional trials using other solvents did not further improve the yield (entries 5-9). 2,2'Bipyridine and 1,10-phenanthroline were tested as ligands, but the yields dropped to 57 and 39\% respectively (entries 10 and 11). Decreasing the catalyst loading to $5 \%$ resulted in a dramatic detriment of the yield (entry 12). When less equivalents of methanol were used (entries 15 and 16), the yields were similar to that found in entry 4 . Finally, decreasing $\mathrm{Mo}(\mathrm{CO})_{6}$ to 0.1 or increasing neocuproine to 0.2 equivalents were found to be less efficient in promoting 2a formation (entries 17 and 18).

Using these optimised conditions, the scope of the reaction was investigated. Substrates were tested including changes in the scaffold of the styrene, as well as that of the double bond, the alcohol and the oxidant. The results showed that this is a robust methodology since it tolerates a wide assortment of modifications. Besides, complete regioselectivity was observed 
Table 1 Optimisation of the reaction conditions ${ }^{a}$

\begin{tabular}{|c|c|c|c|c|}
\hline & $\mathrm{Mc}$ & $\begin{array}{l}\text { u salt, Ligand, } \\
\text { Ph-I=N-Ts } \\
\text { MeOH } \\
(\mathrm{CO})_{6, \text { Solvent }} \\
\mathrm{O}^{\circ} \mathrm{C}, 15 \text { min }\end{array}$ & o & \\
\hline Entry & Copper salt $10 \%$ & Ligand 10\% & Solvent & Yield $^{b, c}[\%]$ \\
\hline 1 & $\mathrm{Cu}(\mathrm{MeCN})_{4} \mathrm{BF}_{4}$ & Neocuproine & DCE & $(48)$ \\
\hline 2 & - & Neocuproine & DCE & - \\
\hline 3 & $\mathrm{Cu}\left(\mathrm{BF}_{4}\right)_{2} \cdot \mathrm{H}_{2} \mathrm{O}$ & Neocuproine & DCE & $53(54)$ \\
\hline 4 & $\mathrm{Cu}\left(\mathrm{BF}_{4}\right)_{2} \cdot \mathrm{H}_{2} \mathrm{O}$ & Neocuproine & $\mathrm{MeNO}_{2}$ & $74(75)$ \\
\hline 5 & $\mathrm{Cu}\left(\mathrm{BF}_{4}\right)_{2} \cdot \mathrm{H}_{2} \mathrm{O}$ & Neocuproine & $\mathrm{CH}_{3} \mathrm{CN}$ & (45) \\
\hline 6 & $\mathrm{Cu}\left(\mathrm{BF}_{4}\right)_{2} \cdot \mathrm{H}_{2} \mathrm{O}$ & Neocuproine & Toluene & (53) \\
\hline 7 & $\mathrm{Cu}\left(\mathrm{BF}_{4}\right)_{2} \cdot \mathrm{H}_{2} \mathrm{O}$ & Neocuproine & $\mathrm{Ph}-\mathrm{Cl}$ & (66) \\
\hline 8 & $\mathrm{Cu}\left(\mathrm{BF}_{4}\right)_{2} \cdot \mathrm{H}_{2} \mathrm{O}$ & Neocuproine & EtOAc & (27) \\
\hline 9 & $\mathrm{Cu}\left(\mathrm{BF}_{4}\right)_{2} \cdot \mathrm{H}_{2} \mathrm{O}$ & Neocuproine & $\mathrm{MeOH}$ & (66) \\
\hline 10 & $\mathrm{Cu}\left(\mathrm{BF}_{4}\right)_{2} \cdot \mathrm{H}_{2} \mathrm{O}$ & $2,2^{\prime}$-Bipyridine & $\mathrm{MeNO}_{2}$ & (57) \\
\hline 11 & $\mathrm{Cu}\left(\mathrm{BF}_{4}\right)_{2} \cdot \mathrm{H}_{2} \mathrm{O}$ & 1,10-Phenanthroline & $\mathrm{MeNO}_{2}$ & (39) \\
\hline $12^{d}$ & $\mathrm{Cu}\left(\mathrm{BF}_{4}\right)_{2} \cdot \mathrm{H}_{2} \mathrm{O}$ & Neocuproine & $\mathrm{MeNO}_{2}$ & (36) \\
\hline $13^{e}$ & $\mathrm{Cu}\left(\mathrm{BF}_{4}\right)_{2} \cdot \mathrm{H}_{2} \mathrm{O}$ & Neocuproine & $\mathrm{MeNO}_{2}$ & $(72)$ \\
\hline $15^{f}$ & $\mathrm{Cu}\left(\mathrm{BF}_{4}\right)_{2} \cdot \mathrm{H}_{2} \mathrm{O}$ & Neocuproine & $\mathrm{MeNO}_{2}$ & (73) \\
\hline $16^{g}$ & $\mathrm{Cu}\left(\mathrm{BF}_{4}\right)_{2} \cdot \mathrm{H}_{2} \mathrm{O}$ & Neocuproine & $\mathrm{MeNO}_{2}$ & (69) \\
\hline $17^{h}$ & $\mathrm{Cu}\left(\mathrm{BF}_{4}\right)_{2} \cdot \mathrm{H}_{2} \mathrm{O}$ & Neocuproine & $\mathrm{MeNO}_{2}$ & $(57)$ \\
\hline $18^{i}$ & $\mathrm{Cu}\left(\mathrm{BF}_{4}\right)_{2} \cdot \mathrm{H}_{2} \mathrm{O}$ & Neocuproine & $\mathrm{MeNO}_{2}$ & (36) \\
\hline
\end{tabular}

${ }^{a}$ Reactions were carried out with $1 \mathrm{a}(1.0 \mathrm{mmol})$ in $3.0 \mathrm{~mL}$ of solvent, $\mathrm{Ph}$ $\mathrm{I}=N$-Ts $\left(1.5\right.$ eq.), $\mathrm{MeOH}\left(10\right.$ eq.), $\mathrm{Mo}(\mathrm{CO})_{6}(0.25$ eq) in an open tube, unless otherwise noted. ${ }^{b}$ NMR-determined yields in a $0.20 \mathrm{mmol}$ scale reaction of $\mathbf{1 a}$ using 1,3,5-trimethoxybenzene as internal standard are shown in parentheses. ${ }^{c}$ Isolated yields. ${ }^{d}$ Catalyst $5 \%$. ${ }^{e} 30$ min. ${ }^{f} \mathrm{MeOH}$ (5.0 eq.). ${ }^{g} \mathrm{MeOH}$ (2.0 eq). ${ }^{h} \mathrm{Mo}(\mathrm{CO})_{6}$ (0.1 eq.). ${ }^{i}$ Neocuproine $(20 \%)$.

considering that only 2-alkoxy- $N$-protected-phenethylamines were detected.

Table 2 displays the outcomes of the reactions using different styrenes under the previously selected conditions, giving rise to products $2 \mathbf{a}-2 \mathbf{p}$ in yields varying from 15 to $92 \%$. Aryl substituents $\left(\mathrm{R}^{1}\right)$ of the styrene used differ not only in electronic nature, but also in their position on the aromatic ring. $\mathrm{R}^{1}$ structure included both electron-donor and electronacceptor groups. Unmodified styrene gave 2a in $75 \%$ yield. The products from alkyl-substituted styrenes, $p$-methylstyrene (2b), $p$-t-butylstyrene (2g) and $m$-methylstyrene (2h) were obtained in 71, 78 and $63 \%$ yield respectively. Compound $2 \mathbf{k}$ was produced from $m$-methoxystyrene in 53\% yield. Halogenated substrates tested including $p$-chloro, $p$-fluoro, and $p$-bromostyrene, providing 2c (64\%), 2e (69\%), 2d (72\%). Furthermore $m$ chloro, $m$-fluoro, and $o$-fluorostyrene produced $2 \mathbf{i}(47 \%), 20$ (56\%) and $2 \mathbf{j}(50 \%)$. An acetoxy substituent at the para-position was also tested, giving $2 \mathbf{f}$ in $92 \%$ yield. A strong electronacceptor group like trifluoromethane at the ortho-position gave $2 p$ in $15 \%$ yield. Other substitutions at the ortho-position such as bromo, methyl and phenyl gave the products $\mathbf{2 q}, \mathbf{2 r}$ and $2 s$ in 43,30 and $65 \%$ yield respectively. Interestingly, no steric hindrance was observed for the latter compound.

When changes in the scaffold of the double bond were made, $\beta$-methylstyrene, an internal alkene, furnished 21 in $31 \%$ yield.
Table 2 Scope of the aminoalkoxylation ${ }^{a}$

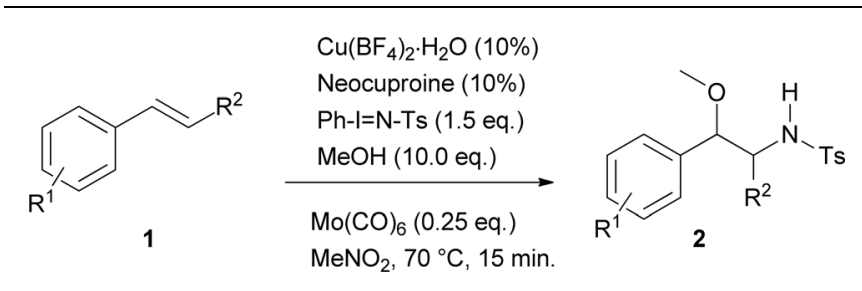

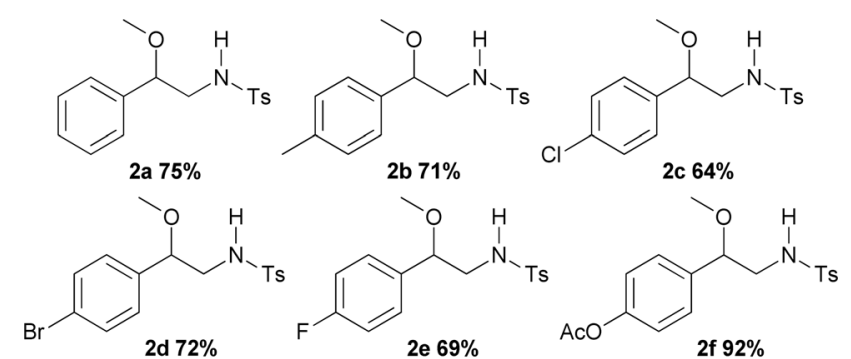

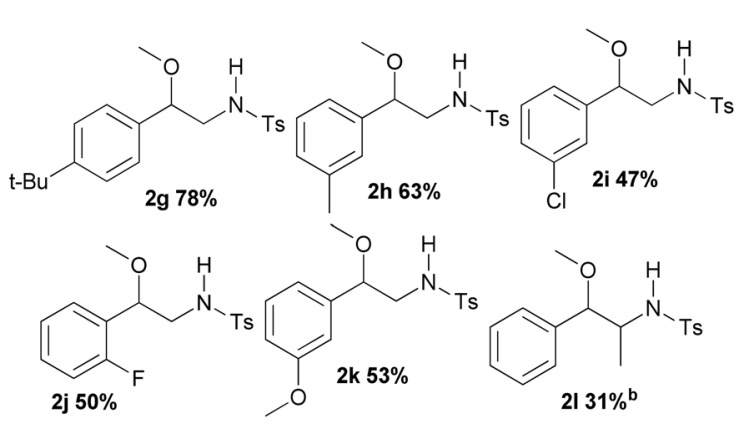

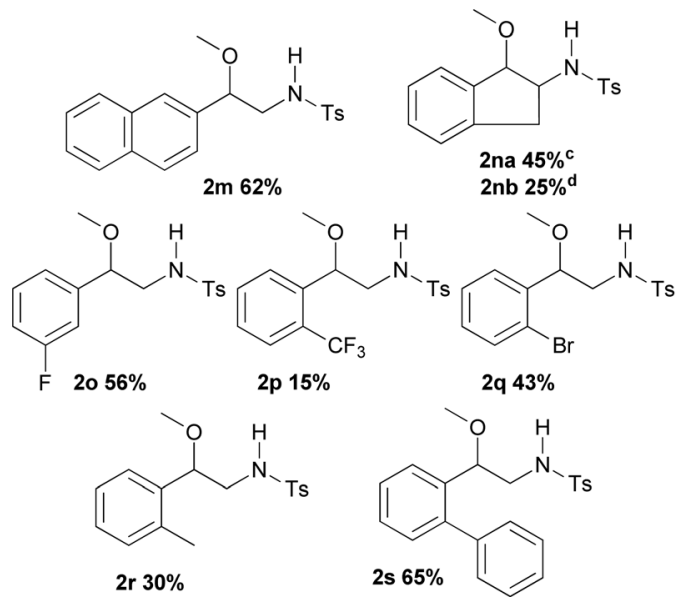

${ }^{a}$ Yields of isolated products after column chromatography of reaction mixtures on a $1.0 \mathrm{mmol}$ scale. ${ }^{b} 5: 1$ ratio of diastereomers determined by ${ }^{1} \mathrm{H}-\mathrm{NMR}$ of the crude product. ${ }^{c}$ syn. ${ }^{d}$ anti.

On the other hand, $1 H$-indene, as an example containing an endocyclic double bond, generated both the (2na) and (2nb) products in 45 and $25 \%$ yield respectively, showing a slight, but not uninteresting diastereoselectivity in this addition reaction. Unfortunately, with ortho or para-methoxystyrene and unactivated olefins (including 1-hexene, 1-octene and cyclohexene) the desired products were not obtained.

Reactions with alcohols other than methanol supplied compounds $\mathbf{3 a}-\mathbf{3 h}$ in yields going from 71 to $41 \%$ (Table 3 ). 
Table 3 Regioselective aminoalkoxylation of styrenes with other alcohols as the oxygen source ${ }^{a}$
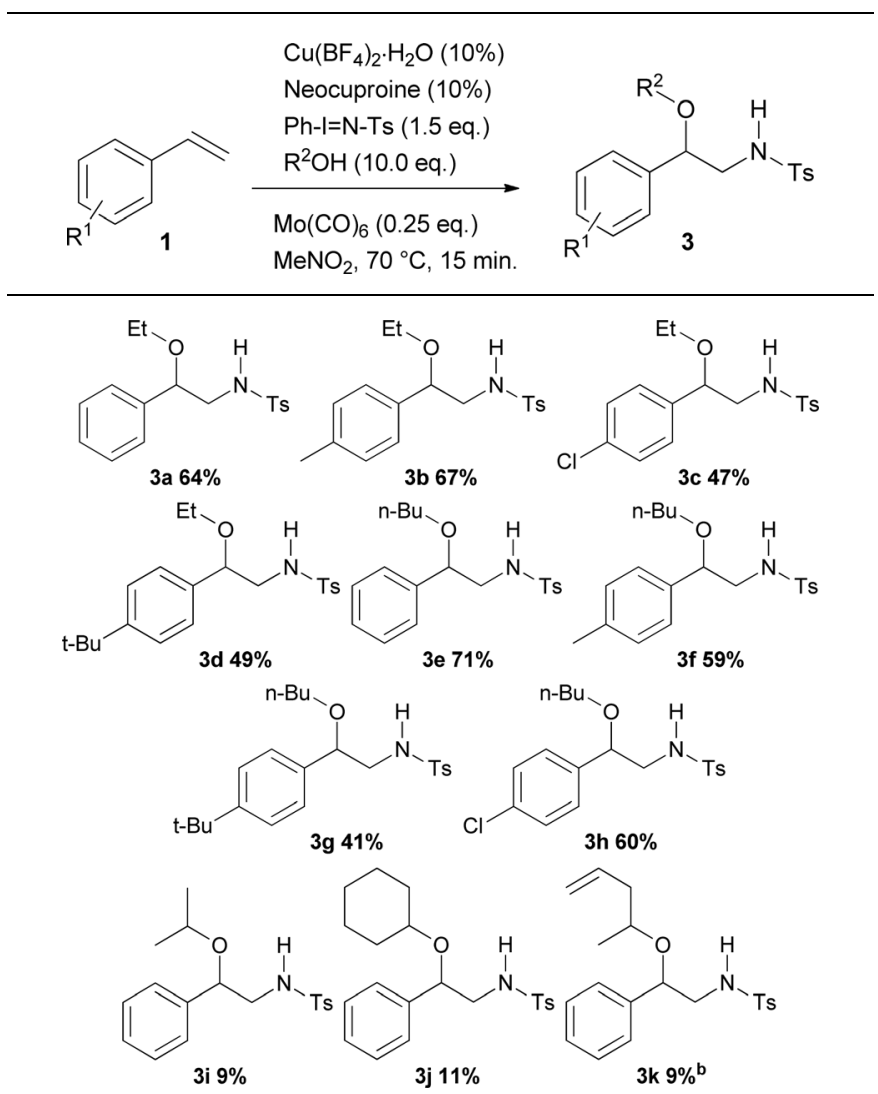

${ }^{a}$ Yields of isolated products after column chromatography of reaction mixtures on a $1.0 \mathrm{mmol}$ scale. ${ }^{b} 1: 1$ mixture of anti and syn diastereomers.

With ethanol and $n$-butanol as reactants and styrene, $p$-methylstyrene, $p$ - $t$-butylstyrene and $p$-chlorostyrene as substrates, the results showed no apparent influence of either the structure of the alcohol or that of the styrene on the reaction yields. Thus, unsubstituted styrene afforded the ethoxy derivative 3a in $64 \%$ and the butoxy derivative $3 \mathbf{e}$ in $71 \%$ yield; $p$-methylstyrene generated the aminoethoxylated and aminobutoxylated products 3b (67\%) and 3f (59\%) respectively. Nevertheless, the reaction of styrene bearing the bulker $t$-butyl substituent showed slightly decreased yields for both the ethoxy (3d) and butoxy (3g) derivatives, 49 and $41 \%$ respectively. On the other hand, aminoalkoxylation of $p$-chlorostyrene with ethanol provided product $3 \mathrm{c}$ in $47 \%$ yield while the reaction with $n$ butanol gave $60 \%$ of the butoxy derivative $3 \mathbf{h}$. Introduction of steric hindrance by using isopropyl alcohol, cyclohexanol and allylmethylcarbinol as reactants, caused a significant decrease in the reaction yields with styrene leading to $3 \mathbf{i}(9 \%), 3 \mathbf{j}(11 \%)$ and $3 \mathbf{k}(9 \%)$ respectively. The structure of $\mathbf{3 d}$ was unequivocally assigned by X-ray diffraction analysis (see $\mathrm{ESI} \dagger$ for more details). ${ }^{11}$

The substrate scope of phenyliodinanes was then investigated. As shown in Table 4, ( $N$-(o- and $p$-nitro phenylsulphonyl) imino)phenyliodinanes were used as oxidants in these
Table 4 Regioselective aminoalkoxylation of styrenes with different phenyliodinanes as the nitrogen source ${ }^{a}$

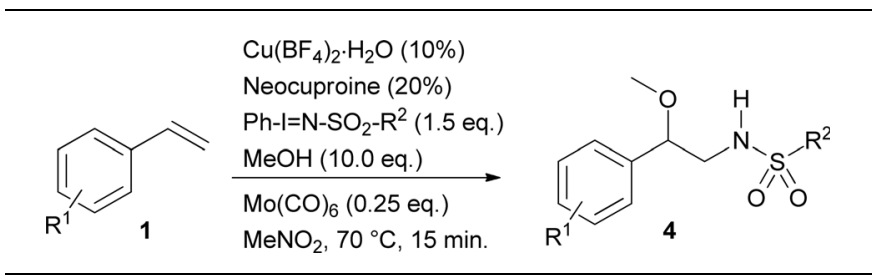<smiles></smiles>

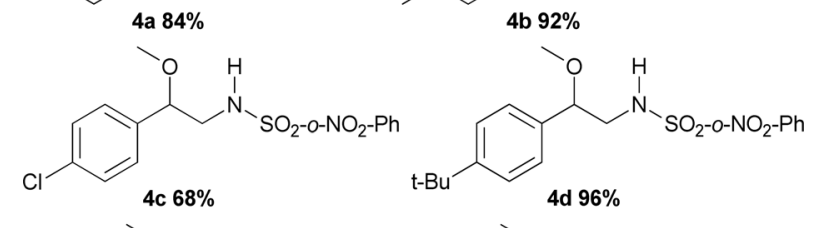<smiles>COC(CNS(=O)(=O)NOc1ccccc1)c1ccc(C)cc1</smiles>

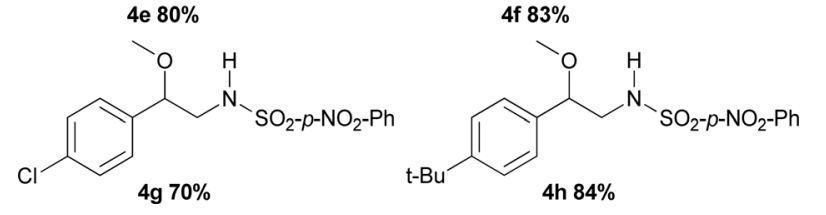

${ }^{a}$ Yields of isolated products after column chromatography of reaction mixtures on a $1.0 \mathrm{mmol}$ scale.

reactions, affording compounds $\mathbf{4 a}$ to $\mathbf{4 h}$. Moderately increased yields were observed when the $N$-(sulphonyl)imino substituent was changed from Ts (Table 2) to $p-\mathrm{NO}_{2} \mathrm{Ph}$ to $o-\mathrm{NO}_{2} \mathrm{Ph}$, for the substrates under study, except for the chloro compound. The products from the reactions of styrenes and $o-\mathrm{NO}_{2} \mathrm{Ph}-,(\mathrm{H}-)$, (Me-), (Cl-) and ( $t$-Bu-)phenyliodinanes, $\mathbf{4 a}, \mathbf{4 b}, \mathbf{4 c}$ and $\mathbf{4 d}$, were obtained in 84, 92, 68 and 96\% yield, respectively. On the other hand, the use of $p$ - $\mathrm{NO}_{2} \mathrm{Ph}$-substituted phenyliodinane as nitrogen source with different styrenes gave $4 \mathbf{e}(\mathrm{H}-), \mathbf{4 f}(\mathrm{Me}), \mathbf{4 g}$ $(\mathrm{Cl}-)$ and $\mathbf{4 h}(t-\mathrm{Bu}-)$ in $80,83,70$ and $84 \%$ yield respectively.

To show the usefulness of the new compounds as building blocks and continuing with our interest in the synthesis of substances with possible activity on neuronal targets, we decided to synthesise the $N$-benzylated derivatives $\mathbf{6 a - 6 f .} .^{\mathbf{1 2}}$ To achieve this goal, we initially took advantage of the acidity of the sulphonamide $\mathrm{N}-\mathrm{H}$ bond present in compounds $2 \mathbf{a}, \mathbf{2 b}, \mathbf{4 d}, \mathbf{4 b}$, 4h and $4 \mathbf{g}$ which were $N$-benzylated using basic alkylation conditions (A) or Mitsunobu conditions (B) furnishing the corresponding $\quad N$-protected- $N$-benzylated- $\beta$-methoxyphenethylamines $\mathbf{5 a}-\mathbf{5 f}$ in yields in the $41-96 \%$ range (Table 5).

In addition, compounds $\mathbf{5 a - 5 f}$ were subsequently deprotected using $\mathrm{Mg}$ in methanol with ultrasound activation (condition C) or basic 2-mercaptoethanol (condition D) for Ts or Ns groups, respectively. ${ }^{\mathbf{1 3 , 1 4}}$ Thus, the desired $N$-benzylated $\beta$ methoxyphenethylamines $\mathbf{6 a - 6 f}$ were obtained in yields in the $23-87 \%$ range (Table 6$)$. 
Table $5 \mathrm{~N}$-Benzylation of methoxysulphonamides ${ }^{a}$
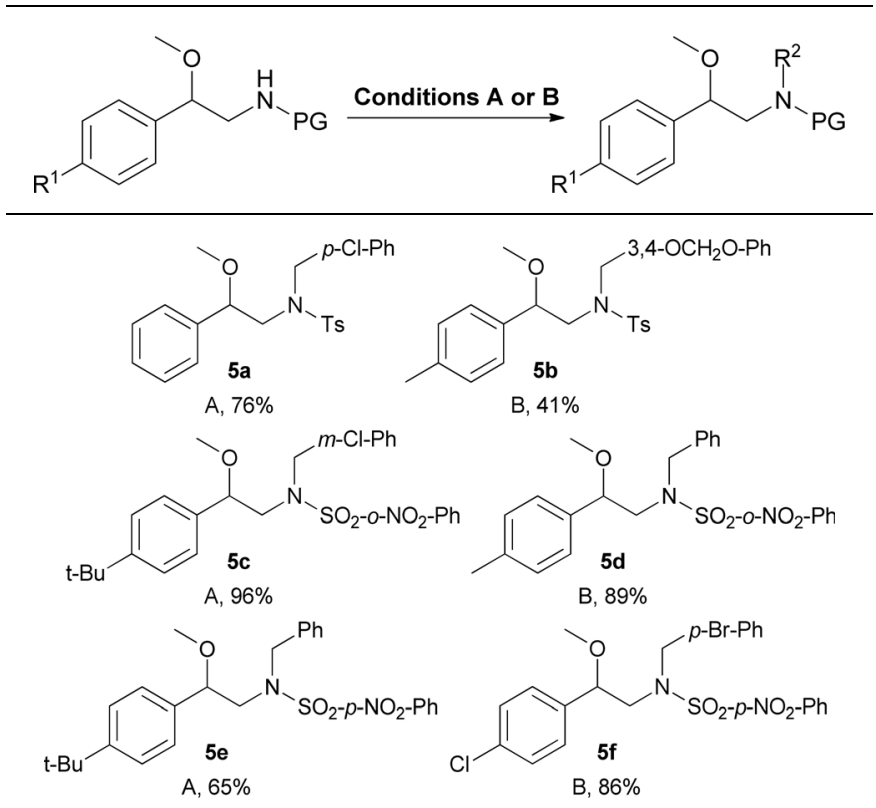

${ }^{a}$ Yields of isolated products after column chromatography of reactions carried out on a $0.5 \mathrm{mmol}$ scale. Conditions: (A) $\beta$ methoxysulphonamide (1.0 eq.), NaH (1.1 eq.), DMF, benzyl halide (1.1 eq.), $0{ }^{\circ} \mathrm{C}$ to r.t., 12 h. (B) $\beta$-Methoxysulphonamide (1.0 eq.), triphenylphosphine (1.4 eq.), benzyl alcohol (1.4 eq.), DIAD (2.0 eq.), THF, $0{ }^{\circ} \mathrm{C}$ to r.t., $12 \mathrm{~h}$.

Finally, we carried out some preliminary experiments to elucidate the role of $\mathrm{Mo}(\mathrm{CO})_{6}$ on the reaction pathway. Tables 7

Table 6 Deprotection of $\beta$-methoxy- $N$-benzyl- $N$-protected phenethyl-amines ${ }^{a}$

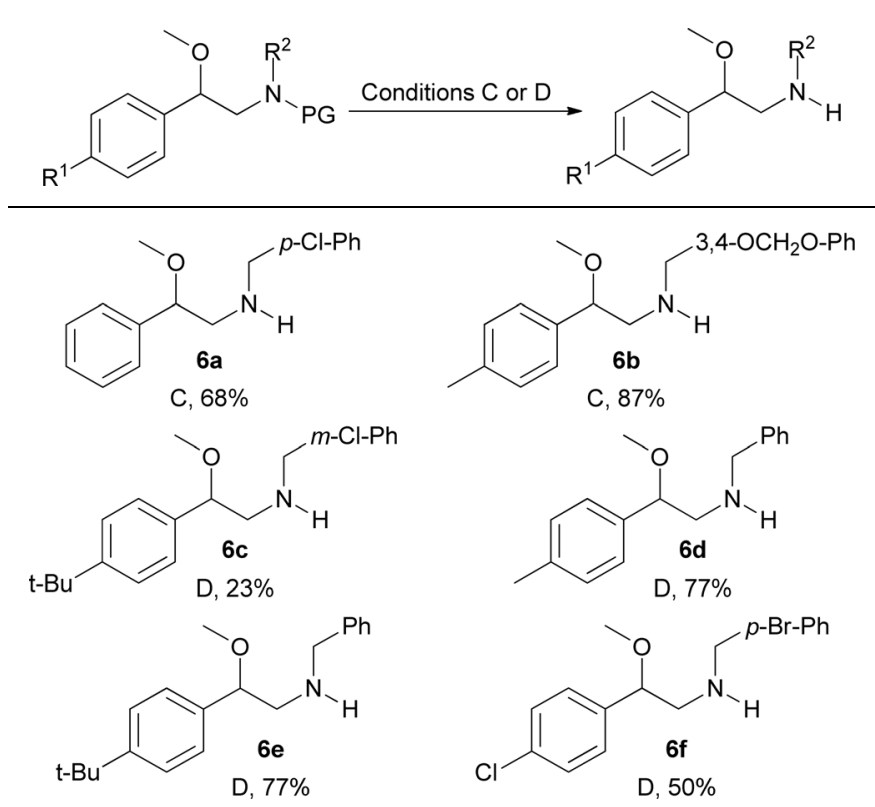

${ }^{a}$ Yields of isolated products after column chromatography of reactions on a $0.3 \mathrm{mmol}$ scale. Conditions: (C) $\mathrm{Mg}, \mathrm{MeOH}$, ultrasound, $1 \mathrm{~h}$. (D) 2Mercaptoethanol, DBU, DMF, r.t., 12 h.
Table 7 Influence of $\mathrm{Mo}(\mathrm{CO})_{6}$ on the nitrene transfer ${ }^{a}$

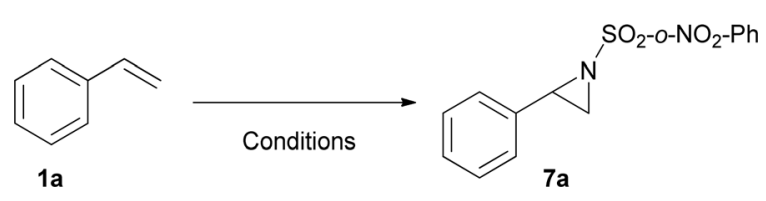

\begin{tabular}{|c|c|c|c|}
\hline Entry & $\mathrm{Cu}\left(\mathrm{BF}_{4}\right)_{2} \cdot \mathrm{H}_{2} \mathrm{O}$ & $\mathrm{Mo}(\mathrm{CO})_{6}$ & Yield $^{b}[\%$ \\
\hline 1 & + & + & 64 \\
\hline 2 & + & - & 6 \\
\hline 3 & - & + & - \\
\hline 4 & - & - & - \\
\hline
\end{tabular}

Table 8 Influence of $\mathrm{Mo}(\mathrm{CO})_{6}$ on the aziridine ring opening ${ }^{a}$

\begin{tabular}{l} 
Entry \\
\hline
\end{tabular}

and 8 show the influence of $\mathrm{Mo}(\mathrm{CO})_{6}$ on the nitrene transfer and aziridine ring opening respectively.

These results suggest that the aziridination reaction requires only the copper salt, but the obtained yield is low (6\%). However, when both copper and $\mathrm{Mo}(\mathrm{CO})_{6}$ are present, the yield rose to $64 \%$, suggesting that the $\mathrm{Mo}(\mathrm{CO})_{6}$ or some of its derivatives is a key to improve the yield under the reaction conditions (Table 7).

In contrast, for the ring opening process, it is clear that the presence of the copper salt is essential but this is not the case for $\mathrm{Mo}(\mathrm{CO})_{6}$ (Table 8). In this sense, and to elucidate how the $\mathrm{Mo}(\mathrm{CO})_{6}$ or its derivative(s) improve the yield of the reaction, other mechanistic studies, including synthesis and characterisation of new organometallic complexes are under way in our laboratory.

Interestingly, based on the abovementioned results, a onepot methodology affords better yields than separated procedures under these reaction conditions. 


\section{Conclusions}

In summary, we have devised a new one-pot copper-catalysed regioselective aminoalkoxylation of styrenes. The reaction takes place through a nitrene transfer, with subsequent opening of the aziridine ring, and proceeds under mild conditions using $\mathrm{Cu}\left(\mathrm{BF}_{4}\right)_{2} \cdot \mathrm{H}_{2} \mathrm{O}$-neocuproine and $\mathrm{Mo}(\mathrm{CO})_{6}$ as the catalytic system. Three different iminoiodanes were used as nitrogen sources as well as primary and secondary alcohols as alkoxy sources. The products obtained should be of interest for the development of $\beta$-alkoxyphenethylamines as new compounds possibly acting on neuronal targets.

\section{Conflicts of interest}

The authors declare no conflicts of interest.

\section{Acknowledgements}

We are grateful for financial support from the Fondo Nacional para el Desarrollo Científico y Tecnológico, Chile (FONDECYT grant 1171391) and FONDEQUIP (grant EQM120021). I. Almodovar thanks the USACH Vicerrectoría de Investigación, Desarrollo e Innovación (grant DICYT-021641AF). P. H.-I. thanks ACT-1404 (IPMaG).

\section{Notes and references}

1 P. A. S. Lowden, in Aziridine Natural Products, ed. A. K. Yudin, Wiley-VCH, Weinheim, 2006, pp. 399-442.

2 (a) D. Tanner, Angew. Chem., Int. Ed. Engl., 1994, 33, 599; (b) Y. Zhu, Q. Wang, R. G. Cornwall and Y. Shi, Chem. Rev., 2014, 114, 8199; (c) C. J. Thibodeaux, W.-C. Chang and H.-W. Liu, Chem. Rev., 2012, 112, 1681; (d) M. Nonn, A. M. Remete, F. Fülöp and L. Kiss, Tetrahedron, 2017, 73, 5461; (e) L. Degennaro, P. Trichera and R. Luisi, Chem. Rev., 2014, 114, 788; (f) W. McCoull and F. A. Davis, Synthesis, 2000, 1347.

3 (a) S. H. Krake and S. C. Bergmeier, Tetrahedron, 2010, 66, 7337; (b) J. A. Kalow and A. G. Doyle, Tetrahedron, 2013, 69, 5702; (c) X. E. Hu, Tetrahedron, 2004, 60, 2701; (d) P. Lu, Tetrahedron, 2010, 66, 2549; (e) Y. Zhao, G. Wang, S. Zhou, Z. Li and X. Meng, Org. Biomol. Chem., 2014, 12, 3362; $(f)$ T. Cytlak, M. Saweliew, M. Kubicki and H. Koroniak, Org. Biomol. Chem., 2015, 13, 10050; (g) L. Ma and J. Xu, Prog. Chem., 2004, 16, 220.

4 (a) N. C. Ghosal, S. Santra, S. Das, A. Hajra, G. Zyryanov and A. Majee, Green Chem., 2016, 18, 565; (b) B. A. Bhanu Prasad, G. Sekar and V. K. Singh, Tetrahedron Lett., 2000, 41, 4677; (c) S. Chandrasekhar, C. Narsihmulu and S. S. Sultana, Tetrahedron Lett., 2002, 43, 7361; (d) H. Stamm and D. Speth, Arch. Pharm., 1989, 332, 277; (e) B. A. Bhanu
Prasad, R. Sanghi and V. K. Singh, Tetrahedron, 2002, 58, 7355; (f) Y. Li, D. Gu, X. Xu and S. Ji, Chin. J. Chem., 2009, 27, 1558; $(g)$ M. Bera, S. Pratihar and S. J. Roy, J. Org. Chem., 2011, 76, 1475; (h) J. Li, Y. Liao, Y. Zhang, X. Liu, L. Lin and X. Feng, Chem. Commun., 2014, 50, 6672; (i) J. Llaveria, A. Espinoza, G. Negrón, M. I. Matheu and S. Castillón, Tetrahedron Lett., 2012, 53, 2525; (j) S. Zhang, C. Shan, S. Zhang, L. Yuan, J. Wang, C.-O. Tung, L.-B. Xing and Z. Xu, Org. Biomol. Chem., 2016, 14, 10973; (k) G. D. K. Kumar and S. Baskaran, Synlett, 2004, 1719.

5 (a) N. Hsueh, G. J. Clarkson and M. Shipman, Org. Lett., 2015, 17, 3632; (b) N. Hsueh, G. J. Clarkson and M. Shipman, Org. Lett., 2016, 18, 4908; (c) J. Zakrzewski, A. P. Smalley, M. A. Kabeshov, M. J. Gaunt and A. A. lapkin, Angew. Chem., Int. Ed., 2016, 55, 8878; (d) M. K. Jackl, L. Legnani, B. Morandi and J. W. Bode, Org. Lett., 2016, 19, 4696.

6 (a) J. Ciesielki, G. Dequirez, P. Retailleau, V. Gandon and P. Dauban, Chem.-Eur. J., 2016, 22, 9338; (b) H. Sun, C. Yang, R. Lin and W. Xia, Adv. Synth. Catal., 2014, 356, 2775; (c) L. Legnani and B. Morandi, Angew. Chem., Int. Ed., 2016, 55, 2248.

7 A. Mal, G. Goswami, I. A. Wani and M. K. Ghorai, Chem. Commun., 2017, 53, 10263.

8 (a) M. A. Torres, B. Cassels and M. C. Rezende, Synth. Commun., 1995, 25, 1239; (b) M. Osorio-Olivares, M. C. Rezende, S. Sepúlveda-Boza, B. K. Cassels and A. Fierro, Bioorg. Med. Chem., 2004, 12, 4055; (c) M. A. Torres, M. C. Rezende and B. K. Cassels, Gen. Pharmacol., 1998, 31, 51.

9 (a) J. Saavedra-Olavarría, G. C. Arteaga, J. J. López and E. G. Pérez, Chem. Commun., 2015, 51, 3379; (b) C. HerreraLeyton, M. Madrid-Rojas, J. J. López, A. Cañete, P. Hermosilla-Ibáñez and E. G. Pérez, ChemCatChem, 2016, 8, 2015.

10 Currently we do not know what the role of $\mathrm{Mo}(\mathrm{CO})_{6}$ may be, but several experiments using different molybdenum salts, in different oxidation states are underway in our laboratories.

11 CCDC 1835571.†

12 (a) J. J. López, E. G. Pérez and J. García-Colunga, Neurosci. Lett., 2015, 607, 35; (b) H. R. Arias, J. J. López, D. Feuerbach, A. Fierro, M. O. Ortells and E. G. Pérez, Int. J. Biochem. Cell Biol., 2013, 45, 2420; (c) E. G. Pérez, C. Ocampo, D. Feuerbach, J. J. López, G. L. Morelo, R. A. Tapia and H. R. Arias, Med. Chem. Commun., 2013, 4, 1166; (d) E. G. Pérez, B. K. Cassels, C. Eibl and D. Gündisch, Bioorg. Med. Chem., 2012, 20, 3719.

13 (a) B. Nyasse, L. Grehn and U. Ragnarsson, Chem. Commun., 1997, 1017; (b) D. A. Alonso and P. G. Andersson, J. Org. Chem., 1998, 63, 9455.

14 T. Kan and T. Fukuyama, Chem. Commun., 2004, 353. 